\title{
Screening for some biological activities of Cultured cordyceps neovolkiana
}

\author{
Chi-Dung Nguyen, Thu Huynh, Minh-Hiep Dinh
}

\begin{abstract}
Cordyceps has been demonstrated to possess a myriad of biological compounds and effects. There are various strains of Cordyceps. In this study, we evaluated some biological activities of cultured Cordyceps neovolkiana extracts. The result exhibited that all $C$. neovolkiana extracts almost showed no toxicity effect on HepG2 cells at the concentration of $100 \mu \mathrm{g} / \mathrm{ml}$. Besides, all $C$. neovolkiana extracts also were not $\alpha$-glucosidase inhibitory activity at the concentration from 1000 to $8000 \mu \mathrm{g} / \mathrm{ml}$. However, some extracts had ABTS ${ }^{\bullet}$ free radical scavenging potential with $\mathrm{IC}_{50}$ values between $4129.92 \pm 25.12$ and $4926.25 \pm 41.01 \mu \mathrm{g} / \mathrm{ml}$. In addition, at $200 \mu \mathrm{g} / \mathrm{ml}$, the EtOH extract exhibited $64.57 \pm 6.30 \% \quad(p<0.001)$ of PBMC proliferation inhibition. In conclusion, these data revealed biological activities of cultured $C$. neovolkiana, suggesting that further studies would be necessary.

Index Terms- Antioxidant, Cordyceps neovolkiana, cytotoxic, a-glucosidase, PBMC
\end{abstract}

\section{INTRODUCTION}

$\mathrm{C}$ ordyceps and related species are a special group of fungi within Hypocreales (Ascomycota) that are parasites of insects, Elaphomyces, nematodes, and plants [7]. More than 400 Cordyceps species have been described worldwide with the highest diversity in East Asia and Southeast Asia. C. neovolkiana is a genus in Cordyceps group [2]. Cordyceps fungi are mostly regarded as bio-controls in agriculture and as precious traditional herbals in Vietnamese and

Manuscript Received on March 15 ${ }^{\text {th }}$, 2017, Manuscript Revised on November 01 ${ }^{\text {st }}, 2017$.

We would like to thank Dr. Binh-Nguyen Truong for providing cultured Cordyceps spp. used in this study.

Chi-Dung Nguyen, Institute of Tropical Biology, Vietnam Academy of Science and Technology and Management Board of Agricultural Hi-Tech Park HCMC.

Thu Huynh, Hochiminh City University of Technology, VNU-HCM

Minh-Hiep Dinh, Management Board of Agricultural HiTech Park HCMC
Chinese traditional medicines [1]. Besides, Cordyceps extracts isolated from cultured Cordyceps had demonstrated to exhibited potential bioactivities, especially antioxidant, cytotoxic and immunomodulatory activities. Hence, this study concentrated on the antioxidant, cytotoxic and immunomodulatory effects of cultured mycelial C. neovolkiana extracts.

To our knowledge, no information is available on the fraction extracts of cultured $C$. neovolkiana. In Vietnam, the fungus has been isolated in Lam Dong province. Therefore, the aim of the study is to determine some biological activities of cultured C. neovolkiana.

\section{MATERIALS AND METHODS}

\subsection{Materials}

Cultured mycelia of Cordyceps neovolkiana was from Nguyen Long Joint Stock Company, Lam Dong Province. The HepG2 cell line was from Department of Genetics, Faculty of Biology and Biotechnology, University of Science, VNUHCM. 2,2-azinobis-3-ehtylbenzothiazolin-6sulfonic acid (ABTS), p-nitrophenyl- $\alpha$-Dglucopyranoside (pNPG), fetal bovine serum (FBS), trypan blue (w/v), phytohemagglutinin PHA, Dulbecco's Modified Eagle's Medium and RPMI 1640 medium (supplemented with 10\% FBS, $10 \mathrm{mM}$ HEPES, $2 \mathrm{mM}$ L-glutamine, 50 $\mu \mathrm{g} / \mathrm{ml}$ Gentamicin, $100 \mathrm{U} / \mathrm{ml}$ Penicillin, 1000 $\mu \mathrm{g} / \mathrm{ml} \quad$ Streptomycin, and $0.25 \mu \mathrm{g} / \mathrm{ml}$ Amphotericin B) were purchased from Sigma Aldrich, Inc., USA. Human peripheral blood mononuclear cells (PBMCs) were obtained from three healthy volunteers who did not use drug for 7 days. Sodium dodecyl sulfate - SDS $\left(\mathrm{C}_{12} \mathrm{H}_{25} \mathrm{NaO}_{4} \mathrm{~S}\right)$ and 3-(4, 5-dimethylthiazol-2- yl)2, 5 diphenyl tetrazodium bromide (MTT) were purchased from Merck Inc. (Germany). Other chemicals and reagents were analytical grade. 


\subsection{Methods}

\subsubsection{Preparation of C. neovolkiana extracts}

The cultured $C$. neovolkiana biomass was dried and extracted in $96 \%$ ethanol (EtOH). Then, petroleum ether $(\mathrm{PE})$, ethyl acetate (EtOAc), nbuthanol $(\mathrm{BuOH})$ and water $(\mathrm{W})$ fractions were obtained in ascending sequence of polarity by liquid-liquid extraction with EtOH extract. Polysaccharide (PS) from residues was extracted by hot water extraction [9].

\subsubsection{Cytotoxic assay}

The cytotoxic screening was measured by the Sulforhodamine B method of the US National Cancer Institute. The HepG2 cells were cultivated on a 96-well plate at an initial density of $10^{4}$ cells/well and pre-incubated for 24 hours before treating with a $100 \mu \mathrm{g} / \mathrm{ml}$ of samples (using Dimethyl sulfoxide (DMSO) $5 \%$ to dissolve samples) and continuously incubating for 48 hours. After that, $10 \%$ Trichloroacetic acid (TCA) was added before keeping at $40^{\circ} \mathrm{C}$ for $1-3$ hours, removing broth and drying at room temperature. Following that, the $0.2 \%$ Sulforhodamine B was added to dye cells at room temperature for 10-15 min. The Sulforhodamine B was removed by $1 \%$ acetic acid. The results were screened by adding $200 \mu 10 \mathrm{mM}$ Tris-base and measuring at $492 \mathrm{~nm}$ and $620 \mathrm{~nm}$. The positive control was camptothecin at concentration of $0.07 \mu \mathrm{g} / \mathrm{ml}$. The cytotoxic activity was calculated by $\left(1-\mathrm{A}_{\mathrm{c}} / \mathrm{A}_{\mathrm{s}}\right) \mathrm{x}$ $100 \%$ with: $\mathrm{A}_{(\mathrm{c} / \mathrm{s})}=\mathrm{A}_{492}-\mathrm{A}_{620}$, where $\mathrm{A}_{492}$ and $\mathrm{A}_{620}$ are the absorbance values at $492 \mathrm{~nm}$ and 620 $\mathrm{nm}$, respectively, $\mathrm{A}_{(492 / 620)}=\mathrm{A}_{\text {cells }}-\mathrm{A}_{\text {blank }}$, where $A_{\text {cells }}$ and $A_{\text {blank }}$ are the absorbance values in the presence and absence of cells, respectively; $A_{c}$ and $\mathrm{A}_{\mathrm{s}}$ are the absorbance values of the control (DMSO $0.25 \%$ ) and tested samples, respectively.

\subsubsection{Determination of the $\alpha$-glucosidase inhibitory}

$\alpha$-glucosidase breaks down starch and disaccharides to glucose related to diabetes. Assay for $\alpha$-glucosidase inhibition was performed by slight modification of a previously published method (Ma et al, 2011). Briefly, solutions of $\alpha$ glucosidase and its substrate (p-nitrophenyl $\alpha$-Dglucopyranoside pNPG) were prepared in phosphate buffer (100 mM, pH 6.9). 5\% DMSO was used as a preferred solvent for preparation of inhibitor solutions. The inhibition assays were conducted by adding inhibitor solution $(50 \mu \mathrm{l})$ to $40 \mu \mathrm{l}$ of enzyme solution $(0.2 \mathrm{unit} / \mathrm{ml})$ in $100 \mathrm{mM}$ phosphate buffer ( $\mathrm{pH}$ 6.8) followed by room temperature for 20 minutes. After pre-incubation,
$40 \mu \mathrm{l}$ of $3 \mathrm{mM}$ substrate (pNPG) prepared in phosphate buffer was added to the mixture to initiate enzymatic reaction. The reaction mixture was incubated at room temperature for 30 minutes, and the reaction was stopped by addition of $130 \mu 1$ of $0.2 \mathrm{M} \mathrm{Na}_{2} \mathrm{CO}_{3}$. Acarbose was used as a positive control. The $\alpha$-glucosidase activity was determined by measuring the p-nitrophenol released from pNPG at $405 \mathrm{~nm}$ using an Elx 800 Micro plate reader. The $\%$ inhibition was calculated using the following equation: Inhibition $(\%)=\left[1-\left(\mathrm{A}_{\text {sample }}-\mathrm{A}_{\text {sample }}^{\prime}\right) /\left(\mathrm{A}_{\text {control }}-\mathrm{A}_{\text {control }}\right)\right] \mathrm{x}$ $100 \%$, where $\mathrm{A}_{\text {sample }}$ and $\mathrm{A}_{\text {control }}$ are the absorbance values of the tested and control (DMSO 5\%) samples, respectively; $\mathrm{A}_{\text {sample }}$ and $\mathrm{A}^{\prime}$ control are the absorbance values of the tested and control (DMSO 5\%) samples without $\alpha$-glucosidase. $\mathrm{IC}_{50}$ values of potent inhibitors were determined by testing 5 serial dilutions of inhibitors and were calculated by using the program Microsoft Excel.

\subsubsection{ABTS ${ }^{+}$radical scavenging assay}

The measurement of ABTS $^{+}$radical scavenging activity was used with some modifications [3]. $7 \mathrm{mM} \mathrm{ABTS}^{++}$was mixed with a $2.45 \mathrm{mM}$ potassium persulphate solution. The reaction mixture was left to settle at room temperature for 12-16 $\mathrm{h}$ in the dark before using. ABTS $^{+}$solution was diluted with phosphate buffer to adjust its absorbance to within $0.70 \pm$ 0.02 at $734 \mathrm{~nm}$. Then, $3 \mathrm{ml}$ of ABTS $^{+}$solution was mixed with $100 \mu 1$ of various concentrations of samples. Vitamin $\mathrm{C}$ was considered as a positive control. Finally, the absorbance was measured at $734 \mathrm{~nm}$ after reaction at room temperature for 30 minutes.

The $\mathrm{ABTS}^{+}$free radical scavenging activity was calculated by the following equation: $(1-$ $\left.\mathrm{A} / \mathrm{A}_{0}\right) \times 100 \%$, where $\mathrm{A}$ and $\mathrm{A}_{0}$ were the absorbance values in the presence and absence of the test samples, respectively. Each experiment was carried out in triplicates and consequences were exhibited as mean $\%$ antioxidant activity \pm SD. The concentration of $50 \%$ inhibition $\left(\mathrm{IC}_{50}\right.$ value) based on the percentage of $\mathrm{ABTS}^{+}$radicals scavenged was calculated from the plotted graph of the means at the concentrations of the samples.

\subsubsection{Preparation of PBMC and}

\section{lymphoproliferation test}

PBMC were isolated from heparinized human peripheral blood of healthy donors. Blood cells were obtained by centrifuging $\left(20^{\circ} \mathrm{C}, 900 \mathrm{rpm}, 30\right.$ min) the mixture of blood and normal saline (v/v:1/1) on Ficoll-Paque (v/v:4/3) gradients as 
described by manufacturer's protocol (SigmaAldrich). The PBMC layers were collected and washed with normal saline solution to remove red blood cells, then centrifuged $\left(20^{\circ} \mathrm{C}, 800 \mathrm{rpm}, 10\right.$ min). The PBMC were dissolved with erythrocytolytic solution from 3-5 minutes at room temperature, and centrifuged $\left(20^{\circ} \mathrm{C}, 2000\right.$ $\mathrm{rpm}, 5 \mathrm{~min})$. The cells were re-suspended in RPMI-1640 medium supplemented with $10 \%$ FBS.

The lymphoproliferation test was modified from MTT colorimetric assay by Mosmann [5]. $100 \mu 1$ of cell suspension adjusted to $1 \times 10^{5}$ cells was applied into each well of a 96-well flatbottomed plate with $100 \mu \mathrm{l}$ fresh medium that containing different concentrations $(0,50,100$, $200 \mu \mathrm{g} / \mathrm{ml}$ ) of extracts. The plates were incubated in $5 \% \mathrm{CO}_{2}$-air humidified atmosphere at $37{ }^{\circ} \mathrm{C}$ for 48 hours. Subsequently, $20 \mu \mathrm{l}$ MTT $(5.5 \mu \mathrm{g} / \mathrm{ml})$ was added into each well. The plates were continually incubated in $5 \% \mathrm{CO}_{2}$-air humidified atmosphere at $37{ }^{\circ} \mathrm{C}$ for 4 hours in dark. Then, 50 $\mu 120 \%$ SDS in $0.02 \mathrm{M} \mathrm{HCl}$ was added into each well, and then incubated for 16 hours. Absorbance was measured with an ELISA plate reader at 570 $\mathrm{nm}$ and $620 \mathrm{~nm}$. All experiments were conducted at least three times [5].

The activity of each extract on PBMC proliferation was calculated by the following formula:

$$
\left.\mathrm{G}(\%)=\left(\mathrm{OD}{ }_{(570-620) \text { samples }} / \mathrm{OD}(570-620) \text { control }\right)-1\right)
$$
$\mathrm{x} 100 \%$

\section{RESULTS AND DISCUSSION}

\subsection{Cytotoxicity effect}

The resuts indicated that the EtOH and fraction extracts of cultured mycelia $C$. neovolkiana displayed weak cytotoxic activity on HepG2 cells (Fig. 1). In this assay, camptothecin was used as a positive control, which inhibited about $58.65 \pm$ $3.57 \%$ of the HepG 2 growth at a concentration of $0.07 \mu \mathrm{g} / \mathrm{ml}$. At $100 \mu \mathrm{g} / \mathrm{ml}$, the cytotoxic activity of EtOH extract on HepG2 was the highest (about $30.19 \%$ ). Wang et. al [11] investigated the inhibitory activity of $\mathrm{HepG} 2$ proliferation of $\mathrm{EtOH}$ extracts and fraction extracts of cultured mycelia $C$. sinensis that were contrast to our present study.

\subsection{ABTS $^{+}$radical-scavenging activity}

The in vitro antioxidant activity of the extracts was determined by using the $\mathrm{ABTS}^{\circ}$ radical scavenging assay. As shown in Fig. 2, the $\mathrm{IC}_{50}$ values of $\mathrm{EtOH}$ and fraction extracts in ABTS free radicals scavenging assays ranged from $4129.92 \pm 25.12 \mu \mathrm{g} / \mathrm{ml}$ to $4926.25 \pm 41.01 \mu \mathrm{g} / \mathrm{ml}$, and $>5000 \mu \mathrm{g} / \mathrm{ml}$, whereas the $\mathrm{IC}_{50}$ value of vitamin $\mathrm{C}$ was about $34 \pm 1 \mu \mathrm{g} / \mathrm{ml}$. Compared to antioxidant activities of polysaccharide extract of C. neovolkiana [6], the $\mathrm{IC}_{50}$ values of ABTS free radical scavenging activity of polysaccharide extract of C. neovolkiana was $2952 \pm 26.56$ $\mu \mathrm{g} / \mathrm{ml}$. The results in this study showed that the antioxidant activity in vitro of polysaccharide extracts of $C$. neovolkiana was higher than solvent fraction extracts of $C$. neovolkiana. Besides, the $\mathrm{IC}_{50}$ values of ABTS free radical scavenging activity of IPS and EPS from Cordyceps sinensis were $1885.90 \pm 2.91$ to $4417.96 \pm 91.16 \mu \mathrm{g} / \mathrm{ml}$, respectively [10]. The comparison exposed higher antioxidant activity of polysaccharide $C$. sinensis extracts than fraction $C$. neovolkiana extracts. In addition, $\mathrm{Wu}$ et al [13] studied the antioxidant activity of polysaccharide fractions purified from Cordyceps militaris. The result attributed to their electron transfer or hydrogen donating ability. It has been suggested the existence of hydroxyl group in polysaccharides could donate electrons to reduce the radicals to a more stable form or reacts with the free radicals to terminate the radical chain reaction. There was a direct correlation between antioxidant activities and reducing power. Furthermore, the presence of reductant associated with the reducing power. Reductant has been shown to exert antioxidant action by breaking the free radical chain by donating a hydrogen atom.

\subsection{The $\alpha$-glucosidase inhibitory activity}

The in vitro $\alpha$-glucosidase inhibitory activity of extracts of $C$. neovolkiana were tested at different concentrations of 125, 250, 500, 1000, 2000, 4000 and $8000 \mu \mathrm{g} / \mathrm{ml}$. In this study, acarbose was used as a positive control with $\mathrm{IC}_{50}=3579.12 \mu \mathrm{g} / \mathrm{ml}$. Results indicated that all extracts were not $\alpha$ glucosidase inhibitors. At $8000 \mu \mathrm{g} / \mathrm{ml}, \alpha-$ glucosidase inhibitory activity of EtOAc extract was the highest with a inhibitory rate of $32.17 \%$. So, it can be concluded that extracts of $C$. neovolkiana were not efficient for $\alpha$-glucosidase inhibiting drug. 


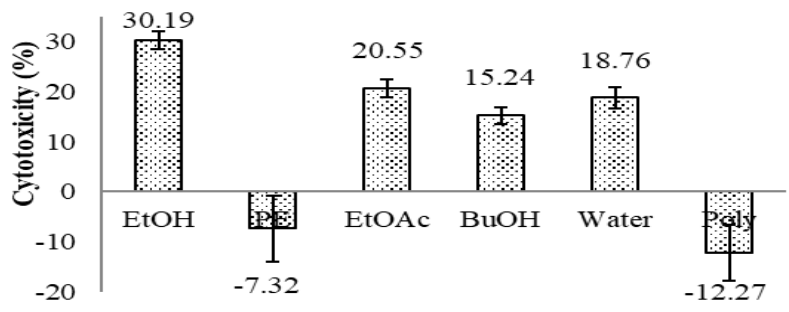

Fig. 1 Cytotoxic activity on HepG2 cells of extracts at $100 \mu \mathrm{g} / \mathrm{ml}$

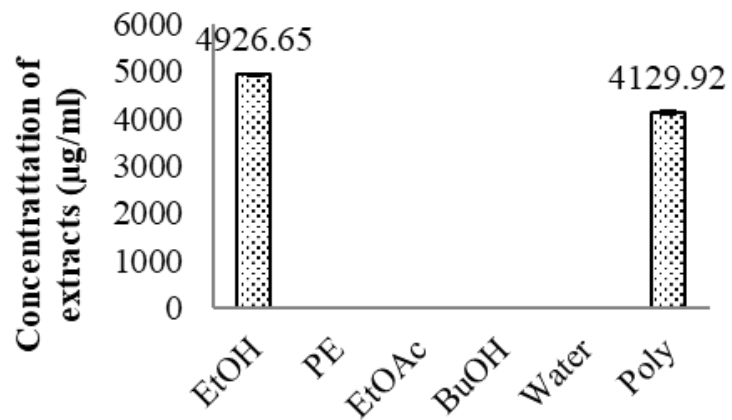

Fig. $2 \mathrm{IC}_{50}$ values $(\mu \mathrm{g} / \mathrm{ml})$ of ABTS radical scavenging activity

TABLE 1

THE COMPONENTS OF COMPLETE BLOOD COUNT OF DONORS

\begin{tabular}{cccccc}
\hline \hline Samples & $\begin{array}{c}\text { Leukocyte } \\
\left(\mathrm{cell} / \mathrm{mm}^{3}\right)\end{array}$ & Neutrophil (\%) & Lymphocyte (\%) & Monocyte (\%) & Eosinophil (\%) \\
\hline Normal & $4000-11000$ & $40-76$ & $24-44$ & $3-10$ & $1-3$ \\
N1 & 7000 & 63.15 & 31.58 & 5.27 & 0 \\
N2 & 5300 & 63.26 & 26.53 & 10.21 & 0 \\
N4 & 6300 & 64.28 & 30.95 & 4.47 & 0 \\
\hline \hline
\end{tabular}




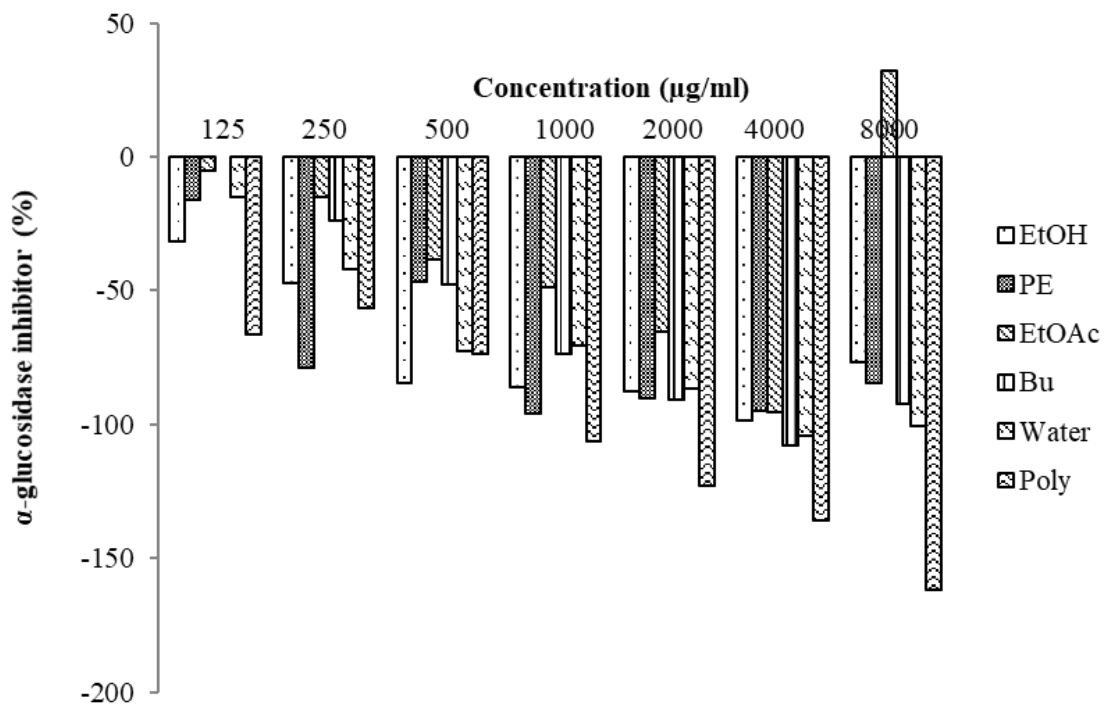

Fig. 3 The rate of $\alpha$-glucosidase inhibitory of C. neovolkiana extracts

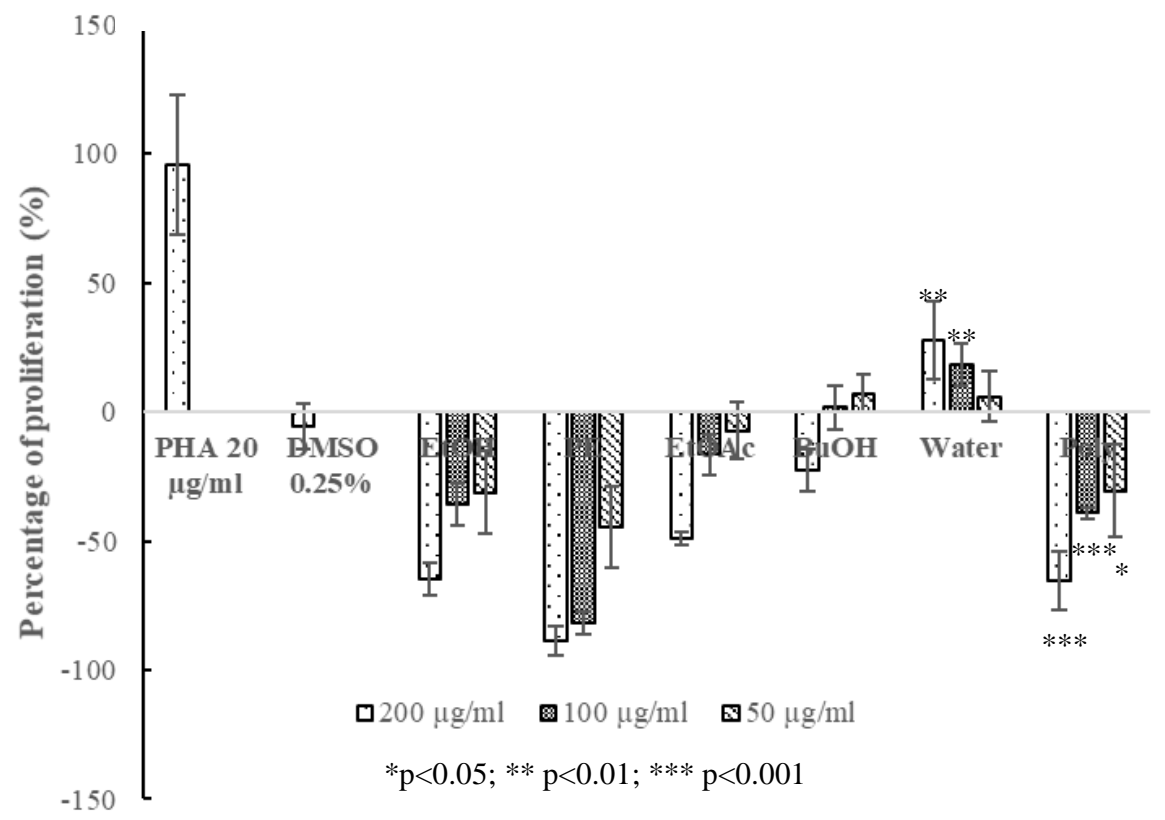

Fig. 4 Effects of C. neovolkiana extracts in PBMC proliferation 


\subsection{The immunomodulatory effect}

Generally, the results showed both enhancing and inhibitory effects of $C$. neovolkiana extracts in human PBMC. The positive control is PHA, a mitogen for $\mathrm{T}$ lymphocytes can bind to $\mathrm{N}$ acetylgalactosamine glycoproteins expressed on the surface of $\mathrm{T}$ cells then activate the cells to produce cytokines and proliferate, which stimulated the proliferation of PBMC to $95.80 \pm$ $27.20 \%$. Besides, both of water and DMSO control showed slight changes of $-6.38 \pm 4.18 \%$ and $-5.65 \pm 8.97 \%$, respectively.

The EtOH extract is crude extract containing all of components in solvent fractions of different polarities. At $200 \mu \mathrm{g} / \mathrm{ml}$, the EtOH extract exhibited a strong inhibition of PBMC proliferation of $-64.57 \pm 6.30 \% \quad(\mathrm{p}<0.001)$. In addition, the results of Wang et al [11] indicated that EtOH extract displayed strong cytotoxic activity on human hepatocellular (HepG2 and Hep3B) and colorectal (HT-29 and HCT 116) carcinoma cells, with an average of low $\mathrm{IC}_{50}$ value $(27 \mu \mathrm{g} / \mathrm{ml})$. The PE and EtOAc extracts obtain components from weak to moderate polarity. All concentration of both were active in inhibiting the proliferation of PBMC, significantly (Fig. 4, $\mathrm{p}<0.05)$.

In contrast, others containing polar compounds demonstrated a trend of high immunostimulating activity. The water extract at $100 \mu \mathrm{g} / \mathrm{ml}$ enhanced steadily the proliferation of PBMC with a stimulation index equal to $27.87 \pm 15.19 \%$, significantly $(\mathrm{p}<0.01)$. Following that, the $C$. neovolkiana extract possesses approximately the enhancement of water extract.

Wei et al [12] concluded that hot-water extract of $C$. sinensis influences to the maturation of human monocyte-derived dendritic cells. Moreover, CS-primed mature dendritic cells displayed increased production of IL-12 and IFN$\gamma$ when co-cultured with allogeneic $\mathrm{T}$ cells. It indicates that the $C$. sinensis extract may help $\mathrm{T}_{\mathrm{h}}$ cells to differentiate into Th1 cells and suggests that $C$. sinensis can be applied as a promising adjuvant in immunotherapy. In addition, natural compounds have traditionally been used and already been proven to be nontoxic. Several studies were reported the in vivo used of $C$. sinensis. Nevertheless, no significant toxic effects were observed in models of Wang et. al indicating that $C$. sinensis is relatively safe for therapeutic purposes [11].

\section{CONCLUSSION}

C. neovolkiana extracts showed weak toxicity effect on HepG2 cells and were not got in $\alpha$ glucosidase inhibitory activity. In contrast to that, C. neovolkiana extracts are able to stimulate the proliferation of PBMC, especially the water extract. In additional, C. neovolkiana extracts were potential antioxidant materials. These data suggest that further studies on in vivo models would be necessary.

\section{REFERENCES}

[1]. Gul, H. T., Saeed, S., Khan, F. Z. A., Entomopathogenic fungi as effective insect pest management tactic: a review, Applied Sciences and Business Economics, 1(1), 10-18 (2014).

[2]. Kobayasi, Y., The genus Cordyceps and its allies, Science reports of the Tokyo Bunrika Daigaku, 5, 53-260 (1941).

[3]. Li Y., Meng S., Wang L., Wang Y., Zu X., Yang Y. and Zhang Z., Antioxidative activity of exopolysaccharide extract from fermented wheat distillers'dried grains using UV-irradiation degradation pretreatment by Preussia aemulans, Adv J Food Sci Technol 6(9), 1067-1075 (2014).

[4]. Ma H.Y., Gao H.Y., Sun L., Huang J., X. Xu M., Wu L.J., Constituents with alphaglucosidase and advanced glycation end-product formation inhibitory activities from Salvia miltiorrhiza Bge, J. Nat. Med., 65 (1), 37-42 (2011).

[5]. Mosmann T., "Rapid colorimetric assay for cellular growth and survival: application to proliferation and cytotoxicity assays", Journal of Immunological Methods, 65, 55-63 (1893).

[6]. Phuong-Tham Ho-Thi, Thi-Tuoi Vu, Thu Huynh, MinhTrang Tran, Thuy-Hang Le-Thi, Minh-Hiep Dinh, Comparison of radicals scavenging activity of exopolysaccharides from cultured Cordyceps spp. isolated in Viet Nam. Jounal of Science and Technology 54 (4A) 148-155 (2016).

[7]. Sung G.-H., Hywel-Jones, N. L., Sung, J.-M., Luangsaard, J. J., Shrestha, B. \& Spatafora, J. W., Phylogenetic classification of Cordyceps and the clavicipitaceous fungi. Studies in Mycology, 57(1), 5-59 (2007).

[8]. Torres, M. S., White, J. F., Clavicipitaceae: Free-living and Saprotrophs to Plant Endophytes, In: Moselio Schaechter (Hrsg.). Encyclopedia of Microbiology, 422430 (2009).

[9]. Phung N.K.P., The methods of extraction of organic compounds, Vietnam National University Publishing House, Ho Chi Minh City, 28-34 (2007).

[10]. Thu Huynh, Minh-Trang Tran, Hoai-Tan Tran, MinhHiep Dinh. The antioxidative and cytotoxic activities of polysaccharides isolated from cultured Cordyceps sinensis, Symposium on Asia Biomedical Research, 2015, Vietnam.

[11]. Wang B.J., Won S.J., Yu Z.R., and Su C.L., "Free radical scavenging and apoptotic effects of Cordyceps sinensis fractionated by supercritical carbon dioxide", Food and Chemical Toxicology, 43, 543-552 (2005).

[12]. Wei C.J., Kuo M.L., Yang R.C,.Chang H.L., and Hsieh C.J., Cordyceps sinensis extract promotes phenotypic and functional maturation of human monocyte derived 
dendritic cells", Journal of Chinese Medicine, 16, 1, 47-55 (2005).

[13]. Wu F., Yan H., Ma X., Jia J., Zhang G., Guo X. and Giu Z., Structural characterization and antioxidant activity of purified polysaccharide from cultured Cordyceps militaris, Afr J Microbiol Res 5 (18) 2743-2751 (2011).

[14]. Vu Tien Luyen, Lao Duc Thuan, Dinh Minh Hiep, Truong Binh Nguyen. - Classification of Cordyceps and related fungi, Journal of Science Ho Chi Minh City Open University, VOL. 1 (17) 29-34 (2016).

Chi-Dung Nguyen: Full name: Nguyễn Chí Dũng. Date of Birth: 15-7-1981. Workplace: Management Board of Agricultural Hi-Tech Park, Ho Chi Minh City, Vietnam. Educational background: Graduation of Bachelor degree in biology was in 2003 at Hue University of Education; Graduation of Master degree of Biochemistry was in 2009 at The University of Science, Vietnam National University Ho Chi Minh City. Main research field in bioactivities of Cordyceps.
Thu Huynh is a researcher at The University of Technology, Vietnam National University Ho Chi Minh City. She graduated Bachelor Engineering of Biotechnology at The Nong Lam University and Master of Biochemistry at The University of Science, Vietnam National University Ho Chi Minh City.

Minh-Hiep Dinh was born in Gia Dinh Province, graduated Bachelor of Biology and Master of Biochemistry at The University of Science, Vietnam National University Ho Chi Minh City, Ho Chi Minh City and PhD of Biochemistry at Institue of Tropical Biology. He mainly studies on Cordyceps spp. and hydrolitic enzymes.

\title{
Khảo sát một số hoạt tính sinh học của nấm Cordyceps neovolkiana nuôi cấy
}

\author{
Nguyễn Chí Dũng, Huỳnh Thư, Đinh Minh Hiệp
}

\begin{abstract}
Tóm tắt- Nhóm Cordyceps đã được biết đến với nhiều hợp chất và hoạt tính sinh học. Nhóm Cordyceps rất đa dạng. Trong nghiên cứu này, chúng tôi đánh giá một số hoạt tính sinh học từ cao chiết sinh khối của Cordyceps neovolkiana. Kết quả thí nghiệm đã chỉ ra rằng cao chiết sinh khối của Cordyceps neovolkiana hầu như không có khả năng gây độc tế bào tại nồng độ $100 \mu \mathrm{g} / \mathrm{ml}$. Bên cạnh đó, tất cả cao chiết sinh khối của Cordyceps neovolkiana không có khả năng ức chế $\alpha$-glucosidase ở nồng độ từ 1000 đến $8000 \mu \mathrm{g} / \mathrm{ml}$. Tuy nhiên, Cao chiết phân cồn và cao phân đoạn có khả năng bắt gốc tự do ABTS từ 4129,2 $\pm 25,12$ tới 4926,25 $\pm 41,01$ and $>5000 \mu \mathrm{g} / \mathrm{ml}$. Thêm vào đó, tại nồng độ $200 \mu \mathrm{g} / \mathrm{ml}$, cao cồn ức chế tăng sinh PBMC 64,57 $\pm 6,30 \%(\mathrm{p}<0,001)$. Điều này chứng tỏ việc nghiên cứu về hoạt tính sinh học của các cao chiết và hoạt chất từ cao chiết Cordyceps neovolkiana là cần thiết.
\end{abstract}

Tù khóa - Cordyceps neovolkiana, sinh khối, cao chiết, $\alpha$-glucosidase, hoạt tính sinh học 